DOI:

http://dx.doi.org/10.15448/1983-4012.2018.1.31467

\title{
SYLLOGIZING AD PROBABILEM IN PSEUDO-SCOTUS
}

Silogismos ad probabilem em Pseudo-Scotus

Guido J. R. Alt*

\begin{abstract}
This essay interprets Pseudo-Scotus' treatise on induction, his seventh quaestio on Aristotle's Analytica Priora. I will emphasize a relevance of this treatise, as already pointed out by Egbert Bos (1991), namely, a new emphasis given to the probable status of general natural principles as the conclusion of inductive syllogisms. This represents an alternative understanding of induction and inductive syllogisms as compared to classical Aristotelian accounts, but it also differs from other approaches to induction in the $14^{\text {th }}$ century. In doing so, I am drawing attention for a thematic already explored before, mainly by E.P Bos (1993, 1991), and also by S. Psillos (2015), but I will seek a contribution on an underexplored topic so far, namely, the role of the notion of probability in this text regarding the justification of induction in later medieval logic and dialectics.
\end{abstract}

Keywords: Pseudo-Scotus; Medieval Philosophy; Induction; Probabilitas.
Resumo: O presente artigo interpreta o tratado de Pseudo-Scotus sobre a indução, a saber, a sétima quaestio acerca dos Analytica Priora de Aristóteles. Irei enfatizar um aspecto da relevância histórica deste tratado, como já apontado por Egbert Bos (1991), a saber, uma nova ênfase dada ao status provável de princípios naturais gerais como conclusões de silogismos indutivos. Isto representou um novo entendimento da indução e de silogismos indutivos, em comparação com abordagens Aristotélicas, mas também em comparação com abordagens alternativas no século 14. Ao fazêlo, irei chamar a atenção para uma temática previamente explorada, principalmente por Bos (1993, 1991) e S. Psillos (2015), mas vou tentar oferecer uma contribuição para um tópico ainda pouco explorado, a saber, o papel da noção de probabilidade neste texto, com respeito à justificação da indução na lógica e dialética tardomedieval.

Palavras-chave: Pseudo-Scotus; Filosofia Medieval; Indução; Probabilitas.

\footnotetext{
* EUmanities Marie Curie Doctoral Fellow at the University of Cologne. I would like to thank the organizers of the Workshop Filosofia e Probabilidade held in 2017 at PUCRS in Porto Alegre, André Neiva, Luis Rosa and Roberto Hofmeister Pich. I am also grateful for the a.r.t.e.s. Graduate School for the Humanities Cologne and European Commission's Maria Sklodowska-Curie Horizon 2020 project, which currently gives me support for the development of my doctoral research.
}

\section{Aristotle on Induction}

The first approach to the problem of how we get knowledge from reasons that are not conclusive

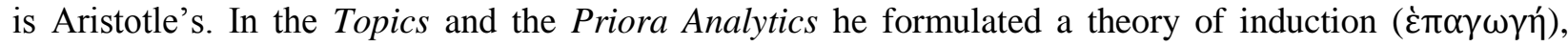

\begin{tabular}{|c|c|c|c|c|c|}
\hline intuitio & $\begin{array}{c}\text { ISSN } \\
1983-4012\end{array}$ & Porto Alegre & Vol.11 $-\mathrm{N}^{\mathrm{o}} .1$ & $\begin{array}{l}\text { Julho } \\
2018\end{array}$ & p.77-85 \\
\hline
\end{tabular}


originally to give an account of how we arrive at general principles from experience, such as the principles of natural philosophy. ${ }^{1}$ As discussed in the Analytica Priora, induction is the mechanism of how we get to general principles about the natural world. As it is known, in the Analytica Priora Aristotle developed the formal theory of the syllogism, which is complemented by the approach of the 'demonstrative syllogism'

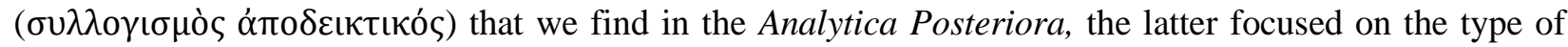
reasoning which transmits knowledge from previously known and evident premises to the conclusion. The demonstrative type of reasoning characterizes infallible or certain knowledge, that is, what Aristotle takes to be epistêmê 'without qualification'. Aristotle builds his deductive system under the assumption that the validity of syllogistic forms (using forms in a rather loose way here) are principled by the inference schemata of perfect deductions or syllogisms. Every other valid possible combination of premises and conclusion is reduced to them; these are, so to speak, the principles of Aristotle's theory of the syllogism considered as an organized science of deductive logic. ${ }^{2}$

But an inductive argument seems to constitute no exception in his treatment of inductive logic, but rather its evaluation is carried forward with a view to the deductive schemata. Aristotle's example for this apparent reductive account of inductive inference to deductive schemata is treated in his developed account of induction, namely in his main account in the Analytica Priora, B 23, especially in 68b15-22. ${ }^{3}$ Aristotle claims in this passage that in an inductive argument the application of a middle term to a subject term is what is being proved in a conclusion, instead of a predicate term: that is, the standard syllogistic form is now rearranged and the original middle term is built into the placeholder of one of the extremes, namely the predicate. His famous example consists of the following inductive syllogism $(A P r$. 68b15; Hinttikka, 2004: 114):

Horses, men and mule are long lived animals.

Horses, men, and mule are bileless animals.

Therefore, every bileless animal is long lived.

Interestingly, Aristotle said that induction proves the middle of an extreme (68b15ff.). We could make the following sense of that. If we take an instance of any normal Barbara scheme $\mathrm{AaB}, \mathrm{BaC}, \mathrm{AaC}$, and switch the role of the placeholder for middle term by the placeholder for one of the extremes, we obtain a syllogism which does not give a "causal reason" as demonstrative syllogisms do. ${ }^{4}$ They would

\footnotetext{
${ }^{1}$ An interesting question is whether inductive syllogisms on such accounts are instances of abductive reasoning. I am not going into this question in this essay.

${ }^{2}$ See J. Hintikka (2004: 111).

${ }^{3}$ J. Hintikka situates other important accounts of induction in Aristotle's ouvre (2004: 116), but recognizes APr. B 23 as the central one.

${ }^{4}$ As it has been pointed out by the medieval authors and imported into the tradition of informal logic, this argument
}

\begin{tabular}{|c|c|c|c|c|c|}
\hline intuitio & $\begin{array}{c}\text { ISSN } \\
1983-4012\end{array}$ & Porto Alegre & Vol.11- $\mathrm{N}^{\mathrm{o}} .1$ & $\begin{array}{l}\text { Julho } \\
2018\end{array}$ & p.77-85 \\
\hline
\end{tabular}


look something like the inference $\mathrm{AaC}, \mathrm{BaC} ; \mathrm{AaB}$. Now, for Aristotle induction presumably generalizes over finite types and not individuals; here $\mathrm{B}$ is co-extensional with $\mathrm{C}$, this gives us an account of the 'necessity in induction', since the terms are convertible. Indeed, for Hintikka (2004: 111ff.), Aristotle in his official account of induction seeks to lay out a way of making an immediate premise plausible. But this is specially the case if Aristotle is referring to a species here, for there a finite number of them, as opposed to individuals. ${ }^{5}$ In this account of the "complete syllogism", Aristotle is interested in reducing inductive arguments to the deductive schemata, by adding in the premises complete generalizations.

If Aristotle develops a theory of complete induction in the APr. B 23, he does develop it for the purpose of making sense of the framework of syllogistic schemata in the case of empirical knowledge. ${ }^{6}$ But the inductive schemata are somewhat derivative, for Aristotle, and they are supposed to establish a necessary conclusion (or an immediate premise for further deductions). Elsewhere in the APo., he describes inductive inference as a cognitive process of concept formation. ${ }^{7}$ In this way, hardly the theory of induction proposes an unequivocal logical approach to the probability of general principles (or immediate premises), since for Aristotle generality builds a sure way to necessity, and those principles are, therefore, statements of necessity.

Aristotelian syllogistic underwent a considerable effort at systematization and unification in the medieval logic. Medieval philosophers inaugurated the approach to the syllogism in a general theory of consequence, especially in the later $13^{\text {th }}$ and $14^{\text {th }}$ centuries, which also encompasses propositional logic, virtually absent from Aristotle's Analytics. We can expect that the theory of inductive syllogism as understood along the lines of APr. B23 played a role within this project. Part of an influential rendering of induction in regimented Latin is adding an iterative cause in the premises, as exemplified by Peter of Spain (Psillos, 2015: 96):

Socrates runs, Plato Runs, and so of all; therefore, all men run.

The central logical item here is the enumerative clause et sic de aliis singulis, (to be picked up later by Ps.-Scotus under the heading of "clausula communis"). The picture suggests something equivalent or at least proximate to Aristotle's doctrine of complete induction, and furthermore makes it explicit that complete enumeration of individual instances is important for 'complete' inductive arguments.

may be seen as a figure of fallacious reasoning, the non distributio medii.

${ }^{5}$ This deviates somewhat from the translation in English by Hugh Trendennick. See E.P. Bos (1991).

${ }^{6}$ This is also accepted by Ps.-Scotus. For him, induction is reducible to syllogistic schemata. See E.P. Bos (1991: 82).

7 Where Aristotle refers to the process of drawing inductions as a concept forming procedure (Psillos, 2015). See also Hintikka (2004: 112).

\begin{tabular}{|c|c|c|c|c|c|}
\hline intuitio & $\begin{array}{c}\text { ISSN } \\
1983-4012 \\
\end{array}$ & Porto Alegre & Vol.11 - N $\mathrm{N}^{\mathrm{o}} .1$ & $\begin{array}{l}\text { Julho } \\
2018 \\
\end{array}$ & p. $77-85$ \\
\hline
\end{tabular}


The notion of 'complete induction' is far from being unproblematic in medieval accounts of empirically based knowledge of general principles. Medieval authors were often engaged in discussion of the justification of induction by what Psillos has called the "induction dilemma" (2015: 98). For them, induction can be either perfect (based on a complete enumeration of cases) or imperfect (not based on a complete enumeration of cases but only on the observation of some). Typically, in the representative example of Aquinas, imperfect induction should be justified as creating knowledge by 'abstraction'; the intellect sees to it, on the experience of some cases or of a single case alone, that a predicate holds of other instances of the same subject, and then a connection between singular and general truths allows for the generalizing clause et sic de aliis singulis. ${ }^{8}$ It is fair to say that the justification of induction was also pursued differently by John Duns Scotus Scotus and William of Ockham (Psillos, 2015), both of whom give it a metaphysical, rather than a cognitive, approach. In Scotus' Ord. I d.3 1.4, we see the use of a meta-principle drawn from the metaphysics of nature to justify induction, namely, the thesis unimpeded free causes yield always the same results (Wolter, 1987: 109). If this account is correct, things appear to have changed with the text we are considering, however, precisely when two texts are considered: our own treatise of Pseudo-Scotus, and also, proximately, John Buridan's Summulae de Dialectica (Psillos, 2015). If a new perspective is generated in these two highly representative texts for later medieval logic, this perspective is closely connected with the view we find in Pseudo-Scotus.

\section{The Probable Syllogism: Pseudo-Scotus' Approach}

The commentary tradition on the Analytica Priora is vast, and for its hardest part, the theory of modal syllogisms, confronted several interpretative problems. Pseudo-Scotus has an important role on this tradition (see Lagerlund, 2000). Although the work of Pseudo-Scotus is hard to situate historically, it was probably written on the first half of the $14^{\text {th }}$ century. This text was for long regarded as one of Scotus' own works in the renaissance and modern editions. The text was formerly included in the Vivès edition (18911895) of Scotus' Opera Omnia, along with several other texts of dubious authenticity - for an overview the editorial history, see Wolter (1987) and E.P. Bos (1993), regarding the commentary to the Analytica Priora in special.

As normal with quaestio-commentaries, it does not have prefixed textual structure set out by the original text, and it does not have a merely exegetical intent, but it seeks to explore philosophical problems within the latter. A quaestio commentary is rather a collection of independent questions. His seventh quaestio is what we are calling here the 'treatise on induction'; it is mainly about the following

\footnotetext{
${ }^{8}$ The intellect's "seeing to it" has been called "generalizing abstraction" by Fr. Raymond. See Psillos (2015).
}

\begin{tabular}{|c|c|c|c|c|c|}
\hline intuitio & $\begin{array}{c}\text { ISSN } \\
1983-4012\end{array}$ & Porto Alegre & Vol.11- $\mathrm{N}^{\mathrm{o}} .1$ & $\begin{array}{l}\text { Julho } \\
2018\end{array}$ & p.77-85 \\
\hline
\end{tabular}


problem: is it required for a good induction induct into ${ }^{9}$ all singulars? Ps.-Scotus seems to refer here that induction is something different from establishing an evident and necessary consequent; it establishes a 'probable' principle or conclusion. A motivation plays a crucial role in evaluating inductive arguments, which replaces the generalizing abstraction model of Aquinas; namely, that inductive support is given not only as the premises give evidence for the conclusion, but by the absence of a counterexample (instantia) to the conclusion. Ps.-Scotus claims that, while seeking to object to an inductive argument, the "respondent" should then either give a counterexample, or introduce a distinction that explains why the predicate applies to some but not all singulars, or show a contradiction follows (meta inopinabile).$^{10}$ This motivation plays a role in establishing inductive syllogisms in the quaestio. After all, the purpose of inductive argumentation is to establish a probable conclusion. For Ps.-Scotus, the status of the general principles which we aim at while construing induction is merely probable, and not necessary. Principles such as omnis ignis est calidus, if they are gained by experience, should then not be proved by any more general or more evident statements; to do so in argumentation would be to commit a fallacious move, if in the context induction should be a kind of ampliative reasoning or a progressio.

It is also important to remark that Ps.-Scotus wants to know if inductive arguments are good without qualification (arguendo absolute). I think the arguendo absolute here contrasts with the 'qualified view' of induction as in Duns Scotus and Ockham, namely, where induction needs a meta-principle in order to be justified. But he is sensitive to the problems a justification of induction can bring about. According to him, we could get to general statements in the conclusion by four mechanisms or inductive procedures (Pseudo-Scotus: 195a; E.P. Bos, 1991: 81):

(1) inducting to all cases sub propria forma by their singular enumeration;

(2) inducting to every singular instances by a common clause which says so and so of every instance of the predicated (et sic de singulis);

(3) inducting to some singular instances sub propria forma;

(4) inducting to some singular instances by a common clause.

He describes the method of inducing from every instance to a conclusion (1) by the way of observing each instance of particulars, enumerating them singularly (enummerando singulatim). But

\footnotetext{
${ }^{9}$ We take here "inducere in" as "induct into", without using his word in any more technical sense.

10 “(...) si fiat inductio in aliquibus singularibus et non habetur evidentia, ut ratio, quoniam ita fir in aliis, oportet quod respondens concedat universalem inductam, vel quod det instantiam in aliquot singulari, vel quod assignet differentiam quare non est ita de aliis singularibus sicut de istis, vel erit reductus ad metam inopinabilem" (PseudoScotus: 196b; E.P. Bos, 1991: 83). With Psillos (2015), could say that for him, as well as for J. Buridan, the intellect has a specific role in induction which differs from the one recognized by Aquinas' and Aristotle's. It seems that Ps.Scotus also took it that the intellect does not reach its target, namely general principles (or immediate premises for further deductions), by "generalizing abstraction". It rather reaches its goal by letting the conclusion survive the test of counterexamples.
}

\begin{tabular}{|c|c|l|l|l|l|}
\hline intuitio & $\begin{array}{c}\text { ISSN } \\
1983-4012\end{array}$ & Porto Alegre & Vol.11- $\mathrm{N}^{\mathrm{o}} .1$ & $\begin{array}{l}\text { Julho } \\
2018\end{array}$ & p.77-85 \\
\hline
\end{tabular}


induction is impossible in this sense, for it is impossible to go through (pertransiri) each singular instance if particulars are infinite. The case is more pressing since Ps.-Scotus does not seek a cognitive justification of induction as Thomas Aquinas does, but he is trying to give a logical account in which each predication must be true of each individual logical subject; there is no abstraction of the form from the concrete individual $a$ so that the intellect could see to it that $P a$ and $P b$. To induce in every case to the conclusion through a common clause (2) is very much the procedure Peter of Spain exemplifies. As Ps.-Scotus remarks, although this is allowed for mathematics (Pseudo-Scotus: 196b; E.P. Bos, 1991: 84), there is a difference the predicates should be observable in our experience, such as being heavy or falling down. In the former case, since our capacity for observation is limited, we cannot 'go through' (pertransiri) infinitely many cases.

Both these positions seem to understand induction as a kind of consequence which is very much reminiscent of the deductive syllogism. This raises problems if induction is an ampliative reasoning or a progression. For one, the premises must be less evident than the conclusion, whereas in deductive syllogisms the contrary is the case. The rationale of this position, most importantly, of the second position sketched above, is explained by Ps.-Scotus. We could argue that a good induction generalizes over all cases necessarily or evidently under a common clause if (2a) everything which leads to the goodness of the induction leads to the truth of the induced universal proposition; ${ }^{11}$ (2b) induction is a kind of locus of going from the parts to the whole; (2c) unless this would be the case, it would follow that an inductive syllogism could have true premises and a false conclusion, which contradicts the account that syllogistic consequence derives with necessity; ${ }^{12}(2 \mathrm{~d})$ if this is not so, it would follow that induction cannot be reduced to the syllogistic figures, since they require universal premises; (2e) induction would be problematic, for a positio (the assertion of one of its premises) could have a counterexample, as Aristotle says in the Topica (Topica I, xi, 104b32-35).

Ps.Scotus earlier already presents an account to reject these four theses in the rationes quod non part. Namely, that in dialectical argumentation (as induction is supposed to be conceived), a petition of principle could not be admitted as good reasoning. But in the account recommended by (2), the premises are so known (aeque notae) as the conclusion, whereas induction is supposed to yield new knowledge. ${ }^{13}$

11 "illud sequitur ad bonitatem inductionis quod sequitur ad veritatem universalis inductae; sed ad veritatem universalis inductee sequitur veritas cuiuslibet eius singularis; igitur et cetera" (Pseudo-Scotus: 195b; E.P. Bos, 1991: $82)$.

12 (...) "nisi ad bonam induction requireretur inductio in omnibus singularibus, sequeretur quod in bona consequentia antecedens esset verum et consequencs falsum, quod est contra definitionem consequentiae datae" (Pseudo-Scotus: 195b; E.P. Bos, 1991: 82).

13 “( $(\ldots)$ in nulla argumentatione dialectica debet committi petitio perincipii; sed inducendo in aliquibus singularibus sub propria forma, et in aliis sub clausula communi, fit petitio principii; igitur et cetera. Maior patet: quia argumentatio dialectica sempre probat conclusionem, et ubi est petitio principii, nulla est probatio. Minor tenet: quia aeque nota est universalis quae debe induci sicut aclausula communis per quam inducitur" (Pseudo-Scotus: 195a;

\begin{tabular}{|c|c|l|l|l|l|}
\hline intuitio & $\begin{array}{c}\text { ISSN } \\
1983-4012\end{array}$ & Porto Alegre & Vol.11- $\mathrm{N}^{\circ} .1$ & $\begin{array}{l}\text { Julho } \\
2018\end{array}$ & p.77-85 \\
\hline
\end{tabular}


Also, what is sufficient for the goodness of inductive reasoning is does not conforms to same standards as deductive syllogisms do. In his definition, Ps. Scotus says that "induction is a progression from some singulars or from every singular instance sufficiently enumerated to the universal conclusion" (PseudoScotus: 197b; E. P. Bos, 1991: 85). Regarding (2d), it is important to note that a positio or the assertion of a premise which is immune to counterexamples is undesirable in the course of inductive dialectical reasoning. To the contrary, induction does not have the purpose of demonstrating "evidently" the conclusion, but to make a probable opinion as a conclusion. This topic is of some importance for Ps.Scotus conclusions.

His conclusions give support for the idea that (3) and (4) are good candidates for an account of how induction works. We will go through the positive part of the treatise on induction. In the first conclusion, he indicates that induction is not valid in order to conclude of necessity, unless it would generalize over all singulars (what is impossible when they are infinite). Otherwise, we would admit a consequence with true premises and a false conclusion (Pseudo-Scotus: 195bf.; E.P. Bos, 1991: 82). The important aspect to note is that induction is not a consequence in the sense which deductive syllogisms are, but inductive syllogisms can nevertheless be good syllogisms. The second conclusion is related with the first one, and indicates that induction is not supposed to conclude evidently, unless the generalization is supported by a universal proposition among the premises. In this case, induction would not need any meta-principle or common clause, for it would be able to enumerate sufficiently and exhaustively. For an example, Ps.-Scotus picks the same one as Peter of Spain did, subtracting the common clause on the grounds of its non-propositionality (namely, the non-propositionality of "and so forth") and postulating a model which the premises exhaust - were "Socrates runs and Plato runs and Cicero runs; therefore, every man runs" to conclude necessarily and evidently, this would only be possible if there were only three men in the world, namely Socrates, Plato and Cicero. ${ }^{14}$

The third conclusion is important. In this context, the notion of probability makes its appearance to qualify the status of the universal conclusion. He operates within the framework of the distinction of probable and closed induction as we see somehow in Albertus Magnus and Thomas Aquinas, as Egbert Bos pointed out, but it does not consider probable induction as a form of imperfect or derivative syllogism. Of particular interest is his III.3:

In order to have a probable belief, creed or persuasion of a universal conclusion, it is sufficient to induce onto some singular cases, and permissible that it is not induced onto every singular case. And hence many inductions are good, arguing absolutely and

E.P. Bos, 1991: 81).

14 "Verbi gratia: posito quod non essent nisi tres homines, scilicet Socrates et Plato et Cicero, tunc sequitur necessario Socrates currit et Plato currit et Cicero currit, igitur omnis homo currit; tamen non sequitur evidenter nisi addatur ista universalis omnis homo est Socrates et Plato et Cicero qua apposite est consequentia evidens" (Pseudo-Scotus: 196a; E.P. Bos, 1991: 83).

\begin{tabular}{|c|c|c|c|c|c|}
\hline intuitio & $\begin{array}{c}\text { ISSN } \\
1983-4012 \\
\end{array}$ & Porto Alegre & Vol.11 - $\mathrm{N}^{\mathrm{o}} .1$ & $\begin{array}{l}\text { Julho } \\
2018 \\
\end{array}$ & p. $77-85$ \\
\hline
\end{tabular}


without any need to induce into every singular case (Pseudo-Scotus: 196a; E.P. Bos, 1991: 83). ${ }^{15}$

Therefore, a universal probable conclusion is precisely what can be legitimately established by induction. Several arguments in support of this are brought out by Ps-Scotus, making it central for the treatise. The first argument claims that good inductive arguments have to conclude more strongly, by bringing in more instances to consideration in the premises, than a single example would, and if it is ascertained that a single example can also make an opinion about other singulars, then much more so does an induction over more instances. ${ }^{16}$

In his second argument on support of the third conclusion, Ps.-Scotus argues that that suffices for a good induction, which suffices for the probability of the universal conclusion of the syllogism, and this means that induction from some instances, but not all, may satisfy these criteria. For as we pointed out above (see n.13), Ps.-Scotus conception of induction has a dialectical motivation regarding counterexamples, and in a dialectical procedure, if a universal positio (as one of the premises) is liable to counterexamples, then it is the role of the 'respondent' to indicate them. The third argument in support of the third conclusion, moreover, states other important motivation in the treatise: namely, that the principles of natural philosophy to be established by induction are probable principles. ${ }^{17}$

A moral which is drawn from these conclusions, and that we can only suspect to concur with Aquinas' theory of the intellect, is that for Ps.-Scotus, the intellect is "more free" in his power to assent than the senses are, for in natural matters it can generalize over all singulars by the evidence of only some instances. ${ }^{18}$ Several objections to the rationale of the reductionist view on induction were rejected, focusing on the fact that induction must be ampliative and yield new knowledge, which means it must be a progressio. For one, induction could only conclude with necessity if it underwent all singular cases; nor is it supposed to do so, for the aim of induction is neither to infer with necessity nor evidently. Induction for Ps.-Scotus is, therefore, a procedure which genuinely yields a probable universal conclusion.

15 "Ad habendum opinionem probabilem, fidem vel persuasionem de conclusione universali, sufficit inducere in aliquibus singularibus, licet non inducatur in omnibus. Et ideo multae inductiones sunt bonae arguendo absolute absque hoc in omnis singularibus inducatur" (Pseudo-Scotus: 196a; E.P. Bos, 1991: 83).

16 “(...) quia fortius potest movere inductio in aliquibus singularibus ad faciendum probabilitatem, fidem vel opinionem de proposiione universali quam potest solum exemplum per unum singulare movere ad faciendum fidem de alio singulari; sed certum est quod solum exemplum per unum singulare facit opinionem de alio singulari, igitur multo forius inductio in aliquibus singularibus facit opinionem de universali" (Pseudo-Scotus: 196a; E.P. Bos, 1991: $83)$.

17 “(...) quia multa principlia naturalia fiunt nobis evidentia propter sensum, memoriam et experientiam, ut ista omnis ignis est calidus; omne grave existens sursum non impeditum naturaliter descendit deorsum et consimilia. Quae facta sunt evidentia per inductionem, et non in omnibus singularibus, ut notum est; igitur sumitur in aliquibus singularibus, et non in omnibus" (Pseudo-Scotus: 196a; E.P. Bos, 1991: 83).

18 “(...) quod intellectus quodammodo magis libere assentit quibusdam quam sensus faciat, sicut in naturalibus propter evidentiam quam habet de aliquibus singularibus statim assentit ita est de omnibus" (Pseudo-Scotus: 196a; E.P. Bos, 1991: 84).

\begin{tabular}{|c|c|c|c|c|c|}
\hline intuitio & $\begin{array}{c}\text { ISSN } \\
1983-4012\end{array}$ & Porto Alegre & Vol.11- $\mathrm{N}^{\mathrm{o}} .1$ & $\begin{array}{l}\text { Julho } \\
2018\end{array}$ & p.77-85 \\
\hline
\end{tabular}


Guido J. R. Alt

Syllogizing ad probabilem in Ps.-Scotus

\section{Final Remarks}

The account of the inductive syllogism we find in Ps.-Scotus implemented Aristotle's classical theory in at least two ways, adding to Psillos (2015) conclusion: he took with J. Buridan the intellect to play a different role than in theories in the model of the 'generalizing abstraction'. The achievements of the intellect, in inductive reasoning, do not consist solely in abstracting data from the senses, but in the search for counterexamples to test natural principles, the concludenda of the inductive argument. The principles thus obtained are not necessary, albeit general, but they are rather general probable principles.

Thus we find in Pseudo-Scotus an interesting attempt at characterizing inductive syllogisms which differs remarkably from the original account of Aristotle's, and also form Aquinas', Ockham's and Scotus' own accounts. For the latter accounts attempt either at a cognitive justification of induction (as Aquinas' account of the generalizing abstraction model) or an account of meta-principles for reasoning about natural matters.

\section{References}

ARISTOTLE. Prior Analytics (transl.n Hugh Tredennick). Cambridge: Harvard University Press, 1962. ARISTOTLE. Posterior Analytics (transl. Hugh Tredennick). Cambridge: Hardvard University Press, 1960. ARISTOTLE. Topica (transl. E.S. Forster). Cambridge: Hardvard University Press, 1960.

BOS, E.P. A Contribution to the History of Theories of Induction in the Middle ages. IN: JACOBI, K. (Ed.). Argumentationstheorie. Scholastische Forschungen zu den logischen und semantischen Regeln korrekten Folgens. Brill: 1993.

BOS, E.P. Pseudo-Johannes Duns Scotus über Induktion. IN: MOJSISCH, B.; PLUTA, O (Eds.). Historia Philosophiae medii Aevi. Studien zur Geschichte der Philosophie des Mittelalters. Festschrift für Kurt Flasch zu seinem 60. Geburtstag, vol. 1. Amsterdam: B.R. Grüner Publishing Company, 1991.

HINTIKKA, J. Analyses of Aristotle. Kluwer Academic Publishers, 2004.

LAGERLUND, H. Modal Syllogistic in the Middle Ages. Brill: 2000.

MCDERMOTT, A. C. S. "Notes on the Assertoric and Modal Propositional Logic of Pseudo-Scotus". Journal of the History of Philosophy, v.10, n.3, pp. 273-306, 1972.

PSEUDO-SCOTUS. Super librum secundum Priorum Analyticorum, quaestio VII, Ed. Paris (Vivès), 1891, pp. 195a-197b.

PSILLOS, S. "Induction and Natural Necessity in the Middle Ages". Philosophical Inquiry, v. 39, n. 1 pp. 92-134, 2015.

WOLTER, A. Duns Scotus. Philosophical Writings: a selection. Indiana: Hackett Publishing Company, 1987.

\begin{tabular}{|c|c|c|c|c|c|}
\hline intuitio & $\begin{array}{c}\text { ISSN } \\
1983-4012 \\
\end{array}$ & Porto Alegre & Vol.11 - N $\mathrm{N}^{\mathrm{o}} .1$ & $\begin{array}{l}\text { Julho } \\
2018 \\
\end{array}$ & p. $77-85$ \\
\hline
\end{tabular}

